\title{
Teaching Programme in Nigerian Higher Institutions: Challenges of Implementation and Way Forward
}

\author{
Ehichoya Edokhamhen ${ }^{1}$ \\ Department of Early Childhood Education \\ East Tennessee State University \\ edemail35@gmail.com \\ Ogunode Niyi Jacob ${ }^{2}$ \\ Ogunodejacob@gmail.com \\ Federal University Wukari, Nigeria
}

\begin{abstract}
This article discusses the challenges militating against effective teaching programme in Nigerian higher institutions. Secondary data were used to support the points raised in the article. The secondary data were sourced from print materials and publications by recognized institutions and individual authors. The article identified inadequate funding of teaching programme, inadequate professional academic staff, poor motivation, inadequate infrastructural facilities, ineffective supervision, unstable academic calendar, brain drain, poor working environment and poor staff development. To address the issues raised, the following suggestions were made: adequate funding of teaching programme, employment of more academic and professional staff, in-service programs for staff development, provision of conducive working environment, provision of adequate infrastructural facilities, and motivation of personnel, effective supervision and implementation of union agreement.
\end{abstract}

Key words: Challenges, Higher institutions, Teaching, Programme, Schools

\subsection{Introduction}

The National Policy on Education (FGN, 2004), defines higher education as post-secondary section of the National Education System, offered by universities, polytechnics, and colleges of technology as well as colleges of education, advanced teachers training colleges, correspondence colleges, and such institutions affiliated to them. According to Adeyemi, (2001), higher education refers to a system which embraces much of the country's research capacity and reproduces majority of the skilled professionals that are required in the labour market. Obanya, (1999) views higher education thus "Higher Education" refers to all organized learning and training activities at the tertiary level. This includes conventional universities, those with the conventional arts, humanities and science faculties as well as specialized universities like institutions specializing in agriculture, engineering, science, and technology. It also includes post-secondary institutions such as the polytechnics and colleges of education. "Higher Education" includes all forms of professional institutions drawing from the available pool of persons who have completed secondary school education: Military institutions, the police, nurses, agriculture, forestry, veterinary workers, catering schools, tourism, secretarial schools are also higher education.

The National Policy on Education (FGN, 2004) regarding Higher education and professional education has the following aims:

(a) the acquisition, development and inculcation of the proper value orientation for the survival of the individual and societies;

(b) the development of the intellectual capacities of individuals to understand and appreciate environment;

(c) the acquisition of both physical and intellectual skills which will enable individuals to develop into useful members of the community;

(d) the acquisition of an overview of the local and external environments (FGN, 2004) Ojo (2006) outlines the following as primary aim of tertiary institutions:

i. Enculturation and progressively equipping the individual, the socio-cultural skills that should enable one to fit neatly into one's immediate society.

ii. Acculturation, progressive exposure to outside influence from which one can intelligently borrow to expand the horizon provided by one's immediate society.

iii. Intellectual skill acquisition, for the pursuit of self-development through the acquisition of knowledge in a variety of forms and by a variety of means.

iv. Affective traits development, progressively improving on the imbibe attitudes, values, and other behavioral traits that facilitate one's relationships with fellow human beings as well as one's capacity for continuous self-employment.

v. manipulative and psychomotor skills development, progressively awaking the physical powers of the individual, and progressively working towards a perfect coordination of activities of the body with those of the mind.

vi. Inculcation of lifelong learning skills (also called learning-to-learn skills), a constellation of activities, habits, mind- 
set, etc. that predispose one to develop the spirit of inquiry and a perpetual thirst for knowledge.

Babalola \& Adedeji (2007) noted that the wealth and poverty of nations depend on the quality of higher education. Those who are poorly educated live a life of a quiet desperation consequently submit to the deceit of politics of patronage, economic sabotage which are threats to sustainable democracy in Nigeria. Udida, Bassey, Udofia, \& Egbona (2009), observed that the above goals as enunciated by the National policy on Education are laudable enough for consideration and utilization by educational managers for the purpose of improving and sustaining Nigerian educational system. It is a statement of fact that the sustainability of institutions, organizations or any society depends largely on the creative capacity of the institution to be capable of effectively performing its functions by offering the required services for the sustenance of the system. Services performed are those that can significantly contribute within the context of a sound macro-economic and political environment to the growth of Nigerian educational institutions and the society.

The National Policy on Education states that higher educational institutions should pursue these goals through: Teaching, Research, the dissemination of existing and new information, the pursuit of service to the community; and by being a store- house knowledge (FGN, 2004).

Saint, Hartmet and Strassner (2003) lamented that the Nigerian university system is performing poorly in the area of teaching and learning in terms of labour market absorption and employers' assessment of graduates. NOUN (2011) submits that concern has been raised about the decline in the quality of education in Universities, Polytechnics and Colleges of Education. This is evident by the quality of graduates produced by these institutions. For instance, graduates from Nigerian universities are faced with problem of unemployment upon graduation. Mohammed and Gbenu (2007) and Obayan (1999) observed that the quality of education offered by higher education institutions in the recent times has deteriorated substantially. Babalola (2007) described the situation in our tertiary institutions as "institutional failure" because of skill mismatch. According to the US Embassy in Nigeria (2012), access to quality education is hampered by the non-enrolment in school of about 10 million out of the 30 million school-age children. The Embassy posits that Nigerian education system suffers from deteriorating quality and insufficient investment to keep pace with the country's burgeoning school-age population. This article is aimed to discuss the challenges preventing effective implementation of teaching programme in the Nigerian higher institutions.

Concept of Teaching

Teaching is the act of imparting knowledge to learners. Teaching is the act of transferring knowledge and skills to students. Teaching is one of the cardinal programme of educational institutions. Teaching is very important in the educational setting. No meaningful educational programme can take place without teaching. Teaching is one of the indicators used for measuring quality of education. There are factors that determine the quality of teaching programme and they include: the quality of the teachers, methods of teaching, classroom management, mastery of subject matter, availability and adequacy of teaching aids, and infrastructural facilities. Olatunji (2013) did a study that examined skills and competencies required for effective teaching and learning in the classroom, most especially in higher educational institution s in Africa. He came up with the concept of pedagogical competence as a comprehensive definition of teaching skills and competencies, which the teacher is expected to have. A scholarly attitude towards the teaching task, in that way, contribute to the formation of knowledge of teaching and learning. Though pedagogical competence includes teaching skills and the scholarship of teaching, it goes beyond them. According to Oldsjo (2010), the traditional view of pedagogical competence is primarily a question of practice "in the classroom" whereby a skillful teacher - through knowledge, methods, actions and ability to communicate - gets teaching situation to function and creates conditions for learning. He, however, pointed out that this view is deficient in the sense that it does not include a scientific attitude towards teaching and learning. He opined that the teacher's ability lies primarily in a scientifically based subject competence and the practical teaching skills that the teacher has acquired and continued to develop.

Apelgren and Giertz (2010) viewed Teaching competence as "the ability and will power to regularly apply the attitude, the knowledge, and the skills that promote students' learning in the best way." This shall be in agreement with the goals within the framework available and presupposes continuous development of the teacher's own competence and instructional design. They highlighted a number of issues in their definition which they deem important for the teacher's pedagogical competence. These include attitude, knowledge, ability, adaptation, perseverance and continuous development. Research has it that competencies needed by university teachers in the Philippines, identified instructional planning, strategies and techniques, communication with learners, learner-reinforcement involvement, and adherence to professional standards as competencies of instructors which affect students' academic performance. Fajonyomi (2007) emphasized that the success or failure of any educational programme rests majorly on the adequate availability of qualified (professional), competent and dedicated teachers. Seweje and Jegede (2005) noted that the ability of a teacher to teach is not derived only from one's academic background but it is based upon outstanding pedagogical skill acquired. The realization of the national growth in technology as highlighted in the Nigeria national policy on education hinge largely on the quality of the teachers.

Challenges of Teaching Programme in Nigerian Higher Institutions

Teaching programme is one of the cardinal programme of higher institutions. The article identified inadequate funding of teaching programme, inadequate academic staff, inadequate professional academic staff, poor motivation, 
inadequate infrastructural facilities, ineffective supervision, unstable academic calendar, brain drain and poor working environment as challenges of teaching programme in Nigerian higher institutions.

\subsection{Inadequate Funding}

Inadequate funding is one of the problems hampering effective implementation of teaching programme in the Nigerian higher institutions. Successful implementation of teaching programme requires a lot of educational resources which are very expensive to acquire. Teaching programme is the first cardinal programme of the higher institutions. To implement it requires the services of professional teachers, availability of teaching aids and conducive teaching environment. In Nigeria, the budgetary allocation for the administration and management of higher institutions is not adequate to acquire all the educational resources required for the implementation of teaching. Udida, Bassey, Udofia, \& Egbona (2009) observed that the major issue in educational development is shortage of funds. One of the most serious problems threatening the survival of the educational systems is that of dwindling level of public funding in the face of rising demands and hence rising cost of higher education. This shortage of funds affects job performance and the growth of the institution. Higher educational institutions cannot perform optimally without funding. This situation calls for increased fund initiative from both the government and educational stakeholders so as to sustain the tempo and growth of the education industry. The inability of the Nigerian government to objectively accept and implement the $26 \%$ funding formula for education recommended by the UNESCO impact negatively on the performance and sustainability of higher education. Thus, it has become obvious that Nigeria's neglect of the funding formula is detrimental to higher educational institution's performance and development aspiration as quality performance is the veritable instrument for sustenance of education system. This neglect has further precipitated crises in the entire higher educational systems as effective teaching, research and service are no longer taking place seriously.

\subsection{Inadequate Academic Staff}

Academic staff are the essential requirement for teaching programme in higher institutions. They plan the lectures, organize the resources and deliver the lectures. Effective teaching progeamme is only possible with the right of academic staff available. It is unfortunate that in Nigeria, majorities of higher institutions are understaffed leading to poor implementation of teaching programme. NEEDS (2014) reported that most recent assessment of manpower needs of Nigerian public universities was conducted in 2012 by an inter-ministerial committee set up by the Federal Government. The aim of this assessment was to elicit information on issues of concern to university education in order to formulate policies and take decisions for addressing such issues. The exercise was conducted to determine, among other issues, the quantity and quality of academic staff required for effective teaching and learning in Nigerian universities. It was intended to be an appraisal of the existing situation in the university subsector with a view to determining what was needed for revitalization and transformation. The needs assessment summary report was presented to the Federal Government in November 2012. It identified manpower shortage as one of the reasons why Nigerian universities have been unable to compete favourably with universities in many other parts of the world. According to the report, a combination of infrastructural and manpower challenges is responsible for the sharp decline in scholarship in Nigerian universities. On manpower challenges, the report indicated that as at November 2012, there were 37,504 academic staff in 74 public universities in Nigeria. Considering the number of staff vis-à-vis the student population, the report revealed an unmanageable lecturer-to-student ratio. For example, at the National Open University, the academic staff-to-student ratio was 1:363, at Lagos State University the ratio was 1:144, and at the University of Abuja the ratio was 1:122. Kano State University, which was 11 years old at the time of the NEEDS assessment period, had one professor and 25 lecturers with PhD degrees, while Kebbi State University had two professors and five lecturers with doctorate degrees. These statistics revealed wide disparities between Nigerian universities and their counterparts in other parts of the world. For instance, the staff-to-student ratio in Harvard University is 1:4, Massachusetts Institute of Technology has 1:9 ratio and the University of Cambridge has 1:3 (NEEDS,2014). It is impossible to effectively implement teaching programme with adequate professional teachers. The understaffing of universities in Nigeria has serious implications for quality instruction and academic productivity in the institutions. The situation has led to an increasing culture of visiting lecturership in the system. The few available qualified lecturers are recycled as visiting, adjunct, sabbatical and contract lecturers to work in many universities at the same time. Many of them are always on the road travelling from one university town to another and unable to meet their primary obligations with their tenure-employer (Federal Ministry of Education, 2012).

\subsection{Inadequate Professional Academic Staff}

Professional academic staff are those who actually have the background of education. They studied education and have necessary skills and methods to impart knowledge. According to NOUN (2011), the employment of teachers in different tertiary institutions takes different forms. However, the minimum entry qualification of a teaching staff into polytechnic is bachelor's degree in relevant field. In Colleges of Education, the National Commission for Colleges of Education (NCCE) requires that candidates to be considered for appointment should have, in addition to first degree, some qualification in education. This means that they have to be certified as professional teachers. The minimum academic qualification required for appointing a university teacher in Nigeria is master's Degree. Occasionally, "persons who earned high quality bachelor's degrees are given positions of Assistant Lecturer", while in some cases, "those who have Second Class (Honours) Upper Division are given the job of a Graduate Assistant" (Mgbekem, 2004). Mgbekem further noted that 
those appointed without the doctoral degree are expected to work and grow through promotions and acquisition of master's and doctoral degrees in their areas of specialization. Nevertheless, for university lectureship, there is an emphasis by the National University Commission (NUC) that the minimum requirement should be a doctoral degree. Government expects that "persons with Third Class (Honors) and Pass degrees are never considered for lectureship appointment (Mgbekem, 2004). To demonstrate her keen interest in teachers' professionalism, the government emphasized in the National Policy on Education, that all teachers in tertiary institutions shall be encouraged to undergo training in the methods and techniques of teaching". To this end, some of the teachers in the universities who are not certified teachers have enrolled for courses leading to the award of a Post Graduate Diploma in Education (PGDE). According to the NEEDS (2012) reports of Federal Government's needs assessment of Nigerian public universities, only about 43 percent of university lecturers have PhD qualifications. The remaining 57 per cent have qualifications below $\mathrm{PhD}$. Only seven universities have up to 60 percent of their teaching staff with PhD qualifications. There are universities with fewer than five professors. For instance, the Kano State University of Science and Technology, Wudil, established 11 years ago and has been turning out graduates, has only one teaching staff with a professor ranking and 25 lecturers who are PhD degree holders. Similarly, the Kebbi State University of Science and Technology, established in 2006, has only two teaching staff in the professor category and five lecturers who have $\mathrm{PhD}$ qualifications. Research has it that students that professional teacher taught performs better than those unprofessional teachers taught (e.g. Owolabi \& Adedayo, 2012). Professionalism in the teaching professional matters. In a situation where professionalism is missing the result is poor performance in the system.

Qualification matter in achieving quality education. Owolabi, \& Adedayo, (2012) finding showed that professional teachers affect the students' performance positively more than the unprofessional teachers. The professional teachers' background training in education is the bane behind this clear-cut difference. No wonder, Fajonyomi (2007) in his study, remarked that the success of any educational enterprise depends largely on the availability of professional teachers. This is possible because the trained teachers have been taught the technical knowhow for effective learning to take place in the learners. Owolabi, \& Adedayo, (2012) did a study that examined the effect of teacher's qualification on the performance of Senior Secondary School students in physics. The purpose was to determine whether the status of the teacher has any impact on the performance of the students in physics. The data collated were analysed using inferential statistics. The results revealed that students taught by teachers with higher qualifications performed better than those taught by teachers with lower qualifications. It was also showed that students performed better in physics when taught by professional teachers. The result also showed that teacher's gender has no effect on their ability to impact knowledge on the students, much as he/she is a skilled teacher in that field of study. However, the experience of the teacher is significant at impacting the students' academic performance in physics. Based on the findings, it was recommended that experienced teachers with professional qualifications in higher level should teach physics at the certificate class.

\subsection{Poor Motivation}

Another factor responsible for poor teaching programme in the Nigerian higher institutions is poor motivation. The academic staff teaching in Nigerian higher institutions are poorly motivated and this directly and indirectly affects their performance. Teaching requires motivated individual to handle it. When teachers are poorly motivated, it affects their productivities which also affects the performances of the students. Bennell and Akyeampong (2007) finds that sizeable percentages of school lecturers are poorly motivated in sub-Saharan Africa and South Asia. Akinfolarin \& Ehinola (2017) did a study that investigated motivation and effective performance of academic staff in higher education. The research design was descriptive survey. The study revealed that encouragement for creativity and innovation, appreciation on genuine effort, award with impressive titles and acknowledge on achievement enhances the performance of university lecturers. Also, 60\% of the respondents agreed that there was lack of provision of regular payment of salary and other remuneration by the head to promote the performance. This study also revealed that provision of adequate chances for professional growth, instructional facilities enhances lecturer's performance. The following recommendations were made; Universities managers and other tertiary institution should continue to provide adequate chances for professional growth and research development, availability of Institutional facilities, good relationship with academic staff and prompt payment of lecturers' salaries to further advance their performance among others.

\subsection{Inadequate Infrastructural Facilities}

Inadequate infrastructural facilities is also another problem preventing effective delivering of teaching programme in most Nigerian higher institutions. Infrastructural facilities are facilities that support the implementation of teaching and researching programme in the educational institutions. Infrastructural facilities like classrooms, laboratories, libraries etc. are not adequate in majorities of higher institutions in Nigeria. Ojo (2006) observed that the problems of inadequate infrastructural facilities are another major constrain to the Universities education development in Nigeria. John, (2016) also remarked that infrastructure facilities and laboratory equipment in our universities are not in good condition and majorities are even outdated. All the required resources for the education production process are in short supply, and this poses a hindrance to learning and research work. The dearth of infrastructure in the universities is sickening and runs short of an ideal academic environment. Today, students are learning in dilapidated buildings. Udida, Bassey, Udofia, \& Egbona (2009) they submitted that the lack of adequate infrastructures in our higher education has posed serious setback in the achievement of higher education goals. In institution where there are no adequate classrooms, resource rooms, staff rooms, laboratory 
facilities, computers and the likes, proper teaching and learning cannot be effective and efficient in the system. Salisu (2001) in her study of influence of school physical resources on students' academic performance concludes that, there is significant difference in the academic performance of students in institutions with adequate facilities and those with inadequate facilities. The lack of good buildings or funds to rehabilitate collapsed structures poses threat to the system's performance and its sustainability; hence, education to some extent is falling due to low standards (Udida, Bassey, Udofia, \& Egbona (2009). Subair, Okotoni, \& Adebakin, (2012) did a study that investigated the place of infrastructure in maintaining quality in Nigerian universities. Using a 20-item self-designed questionnaire and Available Infrastructure Checklist (AIC), data were collected from a random sample of 800 final year students drawn from federal (300) and state (500) universities in the country. The data were analysed using the t-test statistic and descriptive statistics. It was found that there is no significant difference in infrastructural development between the state and federal universities. The study reported that the amount of infrastructure in Nigerian universities is relatively low and grossly inadequate. Thus, it is recommended that government increases funding towards development of the infrastructure. It is also recommended that universities adhere to appropriate standards of infrastructure maintenance and enroll only those students for whom they have adequate facilities to cater for.

\subsection{Ineffective Supervision}

Ineffective supervision is also responsible for poor teaching programme in higher institutions in Nigeria. The Nigerian government, in bid to ensure effective supervision of teaching programme in the higher institutions, established the following agencies: universities are supervised by the National Universities Commissions, while colleges of education are supervised by the National Commission for Colleges of Education (NCCE). The National Board for Technical Education (NBTE) oversees polytechnic education. These commissions are responsible for policy decisions affecting institutions under their supervision, maintenance of standards through a system of periodic accreditation of courses, distribution and monitoring of government funding, appointment of members of governing councils, and the day-to-day running of the institutions (NEEDS, 2014). These supervisory agencies of higher institutions have not been effective in supervision of teaching programme at the various higher institutions due to many challenges that include underfunding, shortage of staffers, weak leadership and internal problems. The inability of these supervisory agencies to effectively supervise the activities of the higher institutions is one of the factors responsible for poor teaching in the higher institutions in Nigeria.

\subsection{Unstable Academic Calendar}

The objective of teaching programme cannot be realized in an educational institution where academic calendar is not stable. Nigerian higher institutions are known for unstable academic programme due to strike by different unions in the various institutions across the country. Teaching is mostly affected whenever there is strike. It affects the implementation of teaching programme as planned. Okoli, Ogbondah, \& Ewor (2016 p. 69) submitted that it has become a known fact that students across various universities in Nigeria are constantly faced with industrial actions embarked upon by the Academic and Non-Academic Staff Unions of various institutions. The disagreement or lack of understanding between government and unions arising from non-implementation of agreement reached, often results in deadlock that usually disrupts academic calendar. As academic activities are suspended for a long period, the students academics suffer. Even the previous knowledge acquired is even forgotten by some students. This mostly turns some students into certificates seekers than knowledge seekers. Ogunode (2020) did a study that investigated the causes of unstable academic calendar in Nigerian higher institutions. Data collected were analyze and it showed that Academic Staff Union of Universities (ASUU)/Nonacademic Staff Union of Universities (NASU) Strike, students' election, communal crisis, increase in school fees, cultic conflict, national programme, and public holiday are factors responsible for unstable academic calendar of higher education in Nigeria. It was also established that half-baked graduates, poor coverage of syllabus, resources wastage, students' involvement in criminal activities and students prolonged years of graduation are the effects of unstable academic calendar. The study recommended that the government should always try to honour whatever agreement reached. Protracted strikes can be averted if necessary steps are taken to build a good relationship between both parties.

\subsection{Brain Drain}

Brain-drain refers to mass movement of professionals especially the academic staff from developing countries to the developed countries for a better job offer. Brain drain is one of the major factors responsible for poor implementation of teaching programme in Nigerian higher institutions. Many experienced academic staff, professors especially, have been moving out of Nigerian higher institutions to developed countries like USA, Germany, UK etc. for better offer. This is affecting the quality of teaching in the higher institutions in the country. For effective teaching to take place, there is need for adequate professional and experienced lecturers in every higher institution. There are many factors responsible for brain drain in Nigeria and they include: poor motivation, unconducive working environment, poor working condition and unattractive salaries. Smah (2007) reports Professor Joseph Stilglitz, 2001 Nobel Prize winner in Economics, who, while delivering a lecture at the first Dr. Pius Okadigbo memorial lecture series in Enugu, Nigeria, said that there is a particular university in the U.S. that has over 25 Nigerian professors. He submitted that the above pointer is instructive for any seriousminded government that wants to address the issue of brain-drain. Bangura (1994) found out that between 1988 and 1990 , over 1000 lecturers left the federal university system in Nigeria. It must be emphasized that while the best brains are leaving the university system, the broad aim of producing high level manpower from the system for national development cannot be achieved. 


\subsection{Poor Working Environment}

Poor working environment is another major factor responsible for poor implementation of teaching programme in Nigerian higher institutions. The working environment of many higher institutions in the country are not conducive for effective delivering of teaching. The environment lacks every educational resource necessary for aiding delivering of teaching programme. Akuezuilo, (2007) who notes that the root disturbing problems of performance and sustenance of higher education in the country could be related to environment. It has been observed that many academic staff have been employed without the adequate designed facilities to cope with and perform their job. This condition among others has resulted in systems poor performance and sustainability of the credible tempo of community service. Besides, we further observed that most of the facilities available are dilapidated and below standard. Accordingly, students' selection procedure is often frauded with abuses and marginalization, number and standard of academic programmes offered are not relevant in some cases to the cultural values and needs of the society, content of courses does not reflect, and the marketable trends of the society, including researches, appointment and retention of teachers, scholars and professional are politicized ((Udida, Bassey, Udofia, \& Egbona.2009, Oni; 2000). These inadequacies cannot promote nor sustain the high-quality standard needed in our higher education.

\subsection{Poor Staff Development Programme}

Training and development is the key to high performance of academic staff in most Universities of the world (Halidu, 2015). Chukwuma, \& Japo (2015) examines staff development and the output of academic staff in the state universities in SouthSouth Nigeria. An ex-post-facto survey design was used to conduct the research in three state universities in the area. Three research hypotheses were formulated to guide the study. Data were collected from a sample of 402 academic staff. This was done using a questionnaire entitled "Academic Staff Development and Academic Staff Output Questionnaire". One-way Analysis of Variance (ANOVA) was used to analyse the data. The findings were that significant relationship exists between staff development and the productivity of academic staff in terms of research, teaching and community service. Therefore, the study concluded that in-service training and attendance of conferences and workshops influence the output of academic staff. Accordingly, it is recommended that adequate funding towards staff development and policies that support staff development are imperative for improved performance.

\subsection{Way Forward}

To address, the article suggests the following: adequate funding of teaching programme, employment of more academic professional staff, in-service program for programme on education, provision of conducive working environment, provision of adequate infrastructural facilities, motivation of personnel, effective supervision and implementation of union agreement.

\subsection{Adequate Funding of Teaching Programme}

Provision of adequate funds for teaching programme is very important because teaching programme in the higher institutions is considered as the most crucial programme that determines the quality of education. So, the government of Nigeria should increase the budgetary allocation of higher institutions so that more funds will be allocated to the teaching programme.

\subsection{Employment of More Professional Staff}

Professional academic staffs are important component of the educational institutions that their availability favour effective implementation of teaching programme at the various higher institutions. The government should develop a strategic plan for manpower production in the higher institutions and employ more academic staff in all the higher institutions in the country.

\subsection{In-service Program for Academic Staff}

The government and higher institutions administrators should develop an in-service program for all the academic staff yet to be certified as professional teachers to go for compulsory educational programme to enable them to improve their capacity of teaching and classroom management.

\subsection{Provision of Conducive Working Environment}

The government and the higher institutions administrators should provide an enabling and conducive environment that will support effective delivering of teaching programme in all the higher institutions in the country. This will motivate teachers to stay in the various higher institutions and work instead of seeking international offers.

\subsection{Provision of Adequate Infrastructural Facilities}

Infrastructural facilities are very important in the realization of the objectives of teaching programme in the higher institutions. The government should provide more infrastructural facilities to all the higher institutions in the country.

\subsection{Motivation of Personnel}

To prevent brain-drain in the Nigerian higher institutions, the government should design a policy and programme that will motivate the academic and non-academic staff work in the country. The salaries and other benefits should be increased and paid as at when due.

\subsection{Effective Supervision}

The government should strengthen all the agencies in charge of supervision of higher institutions in the country and ensure all the supervisory agencies are doing their job as mandated. This will help to improve the supervision of higher institutions. Higher institutions administrators should also put measures down to ensure internal supervision of teaching programme in their respective schools. Ojugwu, (2001) maintains that supervision creates the awareness of sound education philosophies in teachers and makes them to be aware of educational policies and reforms. Thus, supervisors are to play leadership roles 
that would stimulate and encourage both staff and students in the system to perform their duties as to achieve the institutional task or objectives. Also, the effective supervision of instruction will help administrators to identify the quality of lecturers in the institution. It will also check and balance academic staff, non-academic staff and students. Through constant monitoring and evaluation of the system activities in terms of effective control by the different heads of units or departments and constant feedback to management and good utilization of reports, the standard in the system would be raised high and sustained (Udida, Bassey, Udofia, \& Egbona.2009).

\subsection{Implementation of Union Agreement}

The government should implement all agreement reached with different union groups in the higher institutions. This will help to reduce the strike actions affecting the academic calendar of higher institutions in the country.

\subsection{Conclusion}

The teaching programme is the first cardinal program of higher institutions and it is one of the major factors that determines the quality of education in all the educational institutions. Teaching programme in Nigerian higher institutions is facing many challenges. This article identified: inadequate funding of teaching programme, inadequate academic staff, inadequate professional academic staff, poor motivation, inadequate infrastructural facilities, ineffective supervision, unstable academic calendar, brain drain, poor working environment and poor staff development as challenges preventing implementation of teaching programme in the Nigerian higher institutions. To address these challenges, the article suggests the following: adequate funding of teaching programme, employment of more academic professional staff, in-service program for academic staff, provision of conducive working environment, provision of adequate infrastructural facilities, motivation of personnel, and effective supervision and implementation of union agreement.

\section{References}

1. Akinfolarin, A. V. \& Ehinola, G. B. (2017). Academic staff in higher education (Case Study of Adekunle Ajasin University, Ondo State, Nigeria). International Journal of Innovation and Research in Educational Sciences, 1(2), 123-127.

2. Adeyemi, K. (2001). Equality of access and catchment area: Factor in university admission in Nigeria. Journal of Higher Education 42, 307 -322.

3. Apelgren, K. and B. Giertz (2010). Pedagogical competence: A key to pedagogical development and quality in higher education. In: A Swedish Perspective on Pedagogical Competence (A. Ryegård, K. Apelgreen and T.A. Olsson, eds.). Uppsala University, Division for Development of Teaching and Learning, Uppsala.

4. Akwezuilo, S, O. (2007). An Appraisal of Administrative Task of School Managers. Unpublished M.ED Thesis. Delta State University, Abraka.

5. Bernadette, C. N., \& Ukaegbu, O. (2017). Impact of poor implementation of welfare policies on training and development on the performance of academic staff in selected Federal Universities in South-South Nigeria. International Journal of Scientific Research and Management (IJSRM), 5(12), 7718-7729.

6. Bennell, P., \& Akyeampong, K. (2007). Teacher motivation in sub-Saharan Africa and South Asia. DFID: London.

7. Babalola, J. B. (2001). University funding, responses and performances under a declining economy in Nigeria. Educational planning and Policy unit, Department of Educational Management, University of Ibadan. Research and Seminar series.

8. Babalola, J. B., \& Adedeji, S. O. (2007). Revitalizing quality higher education in Nigeria: options and strategies in Babalola, J. B. Akpa, G. O., Ayeni A. O. \& Adsedeji S. O. (eds). Equity quality in higher education. NAEAP.

9. Babalola, J. B. (2008). Modelling Nigerian University System for Effective Learning and Global Relevance. Ibadan: Awemark.

10. Bangura, Y. (1994). Intellectuals, economic reform and social change: Constraints and opportunities in the formation of a Nigerian technocracy. Dev. Change 25(2), 261-305.

11. Chukwuma, N. O., \& Japo, O. A. (2015). Academic staff development and output in state universities in South-South Nigeria. Makerere Journal of Higher Education, 7(2), 49 -

12. Fajonyomi, A. A. (2007). Reviving higher education relevance in Nigeria. A paper presented at the 3rd Faculty of Week and Annual National Conference, Faculty of Education. University of Maiduguri on the theme Higher education reforms in Nigeria from 26th to 27th September.

13. Federal Republic of Nigeria (2004). National Policy on Education. Lagos: NERDC Press.

14. Federal Ministry of Education (FME) (2011). Digest of Educational Statistics. FME, Abuja.

15. Halidu, S. G. (2015). Assessment of funding of federal universities in Nigeria: Evidence from Ahmadu Bello University. Yobe Journal of Economics (YOJE), 2(1), 272-283.

16. John, E. T. (2014). Higher Education in Nigeria. Benx Publisher. Lagos. P-78 
17. Mgbekem, S. J. A. (2004). Management of University Education in Nigeria. Calabar:University of Calabar Press.

18. Mohammed, M. O. B., \& Gbenu, J. P. (2007). Public Universities on the Brink of Collapse in Nigeria Private Sector Participation as a way out. In Babalola J.B., Akpa G. O., Ayeni, A. O. and Adedeji, S. O. (Eds). Access, Equity and Quality in Higher Education. Ibadan: NAEAP 63-73.

19. National Universities Commission (2006). Counting the Blessings of Obasanjo Administration to the Nigerian Universities System. A memo.

20. National Economic Empowerment Development Strategy (NEEDS) (2014). Needs assessment in the Nigerian education sector. International organization for migration, Abuja, Nigeria.

21. NOUN (2011). Issues and Problems of Higher Education in Nigeria. Lagos, Nigeria

22. National Commission for Colleges of Education (NCCE) (1996). Teacher education, an imperative for national development. Abuja, Nigeria

23. Oni, V. T. (2000). State of Higher Education Performance in Nigeria. An International reference. Indiana: Indiana Press.

24. Ojo, L. B. (2006). Total quality management and productivity improvement amongst teachers and learners in private school secondary schools in Lagos state, Nigeria. A postfield report presented at the department of educational management, University of Ibadan. Nigeria. $\quad$ February 2006.

25. Obanya, P. (1999). Higher Education for an emergent Nigeria. Faculty of education, University of Ibadan 5th Anniversary Lecture, Ibadan. Heinemann Education Books (Nigeria Plc).

26. Ojogwu, C. M. (2001). Supervision as an instrument for maintaining standard and quality control in school in current issues in educational management in Nigeria. Being a lead paper presented at the first annual National conference organized by the association for encouraging qualitative education in Nigeria at Enugu State University of Science and Technology (ESUT).

27. Okoli, N.J., Ogbondah, L. \& Ewor, R.N. (2016). The History and Development of Public Universities in Nigeria Since 1914, International Journal of Education and Evaluation, 2(1), 322-323.

28. Olatunji, M. O. (2013). Ensuring and promoting the pedagogical competence of university lecturers in Africa. Journal of Educational and Instructional Studies in the World, 3(3), 73-85.

29. Owolabi, O. T. \& Adedayo, J. O. (2012). Effect of teacher's qualification on the performance of senior secondary school physics students: Implication on technology in Nigeria. English Language Teaching, 5(6), 72-77.

30. Oldsjö, F. (2010). Some thoughts from a pedagogical expert. In: A Swedish Perspective on Pedagogical Competence (A. Ryegård, K. Apelgren and T. Olsson, eds.). Uppsala University, Division for Development of Teaching and Learning, Uppsala.

31. Ogunode, N. J. (2020) An Investigation into the Causes of Unstable Academic Calendar in Nigeria Higher Institutions: A case Study of Federal University Wukari, Taraba,Nigeria. $\quad$ Social Science Researcher, 6 (1) I.D. 6.1.1

32. Salisu, R. A. (2001). The influence of school physical resources on students academic performance. Unpublished M.Ed. dissertation, department of Educational Administration, University of Lagos - Nigeria

33. Saint, W., Hartnet, T. A., Strassner, E. (2003). Higher education in Nigeria: a status report. Higher Education Policy. 16, 259-281.

34. Seweje, R. O., \& Jegede, S. A. (2005). Science education and science teaching methods. Lagos: Atlantic Association.

35. Subair, S. T., Okotoni, C. A., \& Adebakin, A. B. (2012). Perceived Quality of Infrastructure in Selected Nigerian Universities. Makerere Journal of Higher Education, 4(1), 111 - 124.

36. Smah, O. S. (2007). Violent campus cultism: Implication for university management. In J. B. Babalola and B. O. Emunemu (eds). Issues in higher education: research evidence from sub-sahara Africa. Lagos: Bolabay Publication..

37. United States Embassy in Nigeria (2012). Nigeria education fact sheet. Available from http://photos.state.gov/libraries/nigeria/487468/pdfs/ January\%20Education\%20Fact\%20Sheet.pdf.

38. Udida, I. A., Bassey, U. U., Udofia, I. U., \& Egbona, E. A. (2009). System performance and sustainability of higher education in Nigeria. A paper presented at the 11thinternational conference of educational management association of South Africa (Emasa) 7th- 9thAugust.

39. Maxsudov, D. (2019). THE DEVELOPMENT OF TRANSMITTED AND RATIONAL TAFSIRS. The Light of Islam, 2019(1), 9.

40. Махсудов, Д. (2020). Развитие исламоведения (корановедения) в Узбекистане: история и современность. Вестник КазНУ. Серия религиоведение, 21(1), 60-67. 